Vol. XXVII No 2021

\title{
FUNDAMENTAL ELEMENTS REGARDING THE ORGANIZATION OF INTERNAL FINANCIAL CONTROL IN PUBLIC ENTITIES IN ROMANIA
}

\author{
Marian JIANU \\ Control and Inspection Corps, Bucharest, Romania \\ jianumarian09@yahoo.com
}

\begin{abstract}
Financial control, as part of internal managerial control and economic control, is an activity of overwhelming importance for the efficient, effective and economical use of resources economic and financial institutions in public institutions and beyond.The profile literature in this field has outlined the conceptual aspects, the necessary classifications and other defining dimensions of financial control as a highly responsible activity, meant to prevent facts contrary to the good management of wealth elements in public institutions and private entities.Preventive financial control, with its two components (own and delegated), is designed and carried out in public institutions according to a very rigorous methodology, meant to grant a visa only to those public money expenditures that meet all the requirements entered in the checklist. inserts requirements regarding the existence of supporting documents, visas, certifications and approvals regarding the legality of operations, the inclusion of amounts in the allocations of budgetary appropriations and the existence of supporting documents specific tooperations.
\end{abstract}

Keywords: control, financial control, preventive financial control, own preventive financial control, delegated preventive financial control, preventive financial control visa, delegated controller

1. Conceptual approaches and classifications of financial control used in public and private institutions in Romania

In this part of our article we will point out essential conceptual and organizational aspects about financial control as part of internal / managerial and economic control.

In the Romanian specialized literature there are at least 4 specialists who in their different works referred to financial control, public institutions, companies or private financial institutions or both sectors in all conceptual, legislative and organizational aspects. We have in mind teachers Munteanu Victor, Roman Constantin, Boulescu Mircea and Mihăescu Sorin.
For a start, we have in mind prof.univ. Munteanu Victor, with the work he coordinated, entitled "Financialaccounting control at enterprises and public institutions. Theory and practiceconcepts, methodology, regulations, application cases. 4th edition revised and added" [1].

In his turn, the university professor Roman Constantin, in the course support for the master's degree in European Public Governance from the Academy of Economic Studies in Bucharest, entitled "Public financial control" [2] addressed exclusively financial control in this sector, starting from the organizational aspects of this control, continuing with the functioning of this control, then with the exercise of the preventive financial control 
and the internal public audit in public institutions and concluding with applicative studies regarding the circuit of the documents of the main economicfinancial operations.

We cannot omit in the suite of important specialists in this field the university professor Boulescu Mircea, with the work entitled "Financial-fiscal control. Second Edition" [3], which focused to a small extent on the financial control of the state in public institutions and largely on the financial control of companies, starting from the concept of financial control, continuing with the financial control of the state, with the fiscal, then with the organization of the financial-fiscal control, with the prevention and fight against corruption, with elements regarding the control of the activity of the economic agents and finalizing with the control of the use of the fiscal electronic cash registers.

Professor Mihăescu Sorin from Iași, in the paper "Financial-banking control. Revised and added 4th edition" [4] researched and highlighted defining aspects related to the theoretical bases of financial control, financial control procedures and techniques, preventive financial control, current operational financial control, subsequent financial control, fiscal control, financial control exercised by Court of Accounts, banking control in the lending process, control of risk management in the banking system and completion of the financial control action.

Financial control, as a specific form of control,verifies by comparison the normative provisions provided by laws, decisions, orders, methodological norms, etc. as the reality, legality, opportunity and efficiency of the operations recorded in acts and documents, establishing the errors, deviations, deficiencies and deficiencies in the economic-financial activity.

The financial control has as object of researchand includes in its sphere the following components: 1) financial relations, phenomena and processes; 2) the process of administration and management of the patrimony and the results of the economic-social activity; 3) all the moments, units and places where material and monetary values are managed and expenses are made [5].

Financial control, in another approach, is an integral part of management and financial management, it is at the same time the expression of an objective need as a form of knowledge, which gives it a much wider scope and multiple meanings that go beyond the strict interest. of the entity. This control that is performed within the entity has a triple meaning, being at the same time a control for itself (an internal control), a control for others (an external control) and a control for the state (a public control) [6].

The financial control in the vision of another specialist in the field, includes in its sphere, under legal, theoretical and practical aspect, the very complex issue, specific to the economic and financial field in its interaction and mutual conditioning with the technical-technological, legal field, etc. Financial control investigates the economic life at micro and macroeconomic level, viewed through the prism of the correctness of operations, but also of the efficiency with which material, financial and human resources are managed, used and spent [7].

As a component of the internal / managerial and the economic, financial control has as objective the knowledge by the state of the way in which the material and financial means are administered by the public commercial companies, the way of making and spending the public money, ensuring the financial balance, achieving economic and financial efficiency, developing the national economy, achieving social progress.

The control has as essential directions the better organization of work, the strengthening of order and discipline in the organization and development of economic activity, technological discipline, efficient 
management of labor, material and financial means, strict observance and application of the country's legislation by all members of society. the organization and scientific management of the entire socio-economic activity based on the coordinates established in the elaboration of development programs, the good development of the process of transforming the decision into action and the action into more efficient results.

Control teams must monitor whether the acts and operations subject to examination cumulatively meet the conditions of legality, efficiency, effectiveness, economy and reality.

The exercise of financial control is necessary on the financial activity of all state bodies, institutions and central and local public authorities, for which the financial control bodies are organized in a certain hierarchy, being invested with control attributions in the budgetary field, or only fiscal, general, or only local.

Financial control ful fills several functions, namely:

1) The evaluation and knowledge functionconsists in determining at a given time, the results obtained and their evaluation by reference to a predetermined system of criteria, in order to become legal or improve the verified activity.

2) The function of prevention of financial control is materialized in the prevention of deficiencies or damages in carrying out economic and financial activities.

3) The documentationfunction presupposes knowledge of the problems that are the object of economic-social development.

4) The recoveryfunction consists in discovering and recovering the damage and taking measures against the guilty.

\section{Normative and organizational approaches of financial control in public institutions in Romania}

For the beginning we will mention that in Romania financial control in public institutions is regulated by two recent relatively normative acts, namely: 1)
OMFP no. 923 [8] of July 11, 2014, for the approval of the General Methodological Norms regarding the exercise of preventive financial control and of the Specific Code of professional norms for the persons carrying out their own preventive financial control activity, republished; 2) OMFP no. 103 [9] of January 16, 2019 on amending and supplementing OMFP no. 923/2014.

The normative act from 2014, on the part of methodological norms, is structured on the following components: A) General provisions; B) Own preventive financial control; C) Delegated preventive financial control; D) Reporting and information.

From the Order of the Minister of Public Finance no. 923 of July 11, 2014 for the approval of the General Methodological Norms regarding the exercise of preventive financial control and the specific Code of professional norms for persons carrying out their own preventive financial control activity, we extracted a series of concepts, classifications and clarifications essential for understanding the current mechanism of this type of control in public institutions at present.

Preventive financial control [10] aims at identifying projects of operations that do not comply with the conditions of legality and regularity and / or, as the case may be, within the limits and destination of budgetary and commitment appropriations and through which the public patrimony and / or public funds.

The own preventive financial control [11] is organized, as a rule, within the specialized financial-accounting departments and in relation to the nature of operations, the head of the public entity may decide to extend it to other specialized departments where it is initiated, by legal acts or found payment obligations or other obligations of a patrimonial nature.

The delegated preventive financial control [12] is exercised at the level of the main authorizing officers of the budgets expressly specified in the Government Ordinance no. 119/1999 (state budget, state social insurance budget, budget of 
any special fund, state treasury budget, for public debt operations); the Minister of Public Finance shall appoint one or more delegated controllers for the operations carried out through the above-mentioned budgets.

The operations that concern, mainly the following aspects are the object of the preventive financial control: 1) legal commitments and budgetary commitments; 2) opening and distribution of budget credits; 3) modification of the distribution by quarters and by subdivisions of the budgetary classification of the approved credits,including by credit transfers; 4) ordering expenses; 5) the establishment of public revenues, regarding the authorization and establishment of the collection titles; 6) the concession or rental of goods belonging to the public domain of the state or of the units administrativeterritorial; 7) sale, pledge, concession or rental of goods belonging to the private domain of the stateor of the administrativeterritorial units; 8) other categories of operations established by order of the Minister of Public Finance.

The public entities where the preventive financial control is organized are: the public authorities and the autonomous administrative authorities; public institutions belonging to the central and local public administration and public institutions fromtheir subordination; autonomous utilities of national or local interest; national companies or societies; the commercial companies in which the state or an administrative-territorial unit holds the majority capital and uses / administers public funds and / or public patrimony; agencies, with or without legal personality, that manage funds from reimbursable or non-reimbursable external financing; The Ministry of Public Finance, for the treasury operations, public debt, the realization of the state revenues and of Romania's contribution to the budget of the European Union; the executive public authorities of the local public administration, for the public debt operations and the realization of their own revenues.

The preventive financial control consists in the systematic verification of the operations that are its object, from the point of view of: a) the observance of all the legal provisions that are applicable to them, in force at the date of performance operations (legality control); b) the fulfillment in all aspects of the principles and of the procedural and methodological rules that areapplicable to the categories of operations to which the operations subject to control belong regularity); c) compliance with the limits and destination of budgetary and / or commitment appropriations, as the case may be (budgetary control).

The own preventive financial control is exercised, by visa, by persons from the specialized departments designated for this purpose by the head of the public entity.

The preventive financial control visa includes the following essential information: a) the name of the public entity; b) the statement "targeted for preventive financial control"; c) the identifier of the visa holder; d) the signature of the person designated with the exercise of the visa and the date of granting the visa (year, month, day). The preventive financial control visa is exercised in handwriting or electronically.

The data from the documents presented at the preventive financial control visa are entered in the register regarding the operations presented at the preventive financial control visa.

The deadline for ruling (granting / refusal of visa) is determined by an internal decision by the head of the public entity according to the nature and complexity of operations in general and / or specific operations subject to preventive control.

The control procedure requires that the Documents regarding the operations through which the public funds and / or public patrimony are affected are accompanied by the opinions of the specialized compartments, of 
substantiation notes, of acts and / or supporting documents and, as the case may be, of a "Proposal for employment of an expenditure within the limits of the commitment appropriations ", a" Proposal for the commitment of an expenditure within the limits of the budgetary appropriations "and / or an" Individual / global budgetary commitment ", as well as the organization, record and reporting of budgetary and legal commitments OMFP no. 1,792 / 2002 [13], with subsequent amendments and completions.

The person designated to exercise the preventive financial control receives the documents, registers them in the register, after which he proceeds to the formal verification by going through the checklist specific to the operation received at the visa, regarding: 1) completing the documents in accordance with their content; 2) the existence of the signatures of the authorized persons within the specialized departments; 3) the existence of supporting documents specific to the operation.

The exercise of the attributions of preventive financial control by the designated persons is carried out on the basis of the following principles: a) professional competence; b) decisional independence in the conditions of separation of attributions; c) objectivity; d) moral conduct; e) confidentiality; f) incompatibility.

Regarding the delegated preventive financial control, it is necessary to emphasize a series of very important aspects.

In its capacity as a specialized body of the Government in the field of finance, the Ministry of Public Finance may exercise, through delegated controllers appointed by the Minister of Public Finance, preventive financial control to some public entities on operations that may affect the balanced execution of budgets or are associated with risk categories determined by the specific methodology of risk analysis.
In order to ensure the financial management, in conditions of legality, economy and efficiency, of the funds granted to Romania by the European Union and to implement the procedures provided in the regulations of the financing bodies, the Minister of Public Finance appoints delegated controllers to the implementation structures.

And on the basis of the activity of the persons fulfilling the mission of granting the delegated financial control visa, a Code of Ethics is established [14] which regulates the norms of conduct of these financial professionals.

The objectives of this code of conduct are to ensure the necessary ethical framework for the profession of delegated controller, so that he can perform his duties with professionalism, loyalty, fairness and conscientiousness and refrain from any act that could harm the institution. or to the public authority in which it carries out its activity, through: a) performance; b) professionalism; c) quality of services; d) trust; e) conduct; f) credibility.

The general principles underlying the profession of delegated controller are the following: a) the supremacy of the Constitution and the law; b) the priority of the public interest; d) impartiality and independence; e) moral integrity; f) freedom of thought and expression; g) honesty and fairness; h) openness and transparency.

The financial control, in the context of its evaluation on the occasion of the examination of the internal / managerial control by the internal public audit and respectively by the external public audit, offered the occasion of both positive and negative findings. These analyzes were performed by the supreme national bodies of external public audit (Court of Accounts) and internal (Central Harmonization Unit for Internal Public Audit-UCAAPI).

We considered it useful to highlight some conclusions found in the most recent analyzes performed by the Court of 
Accounts on the negative aspects resulting from the financial control activity in public institutions (aspects highlighted by the evaluations performed on financial control by internal and external public auditors).

We have in mind the Special Report on the activity of public internal audit structures at the level of central public administration authorities prepared by the Court of Accounts in 2018 [15].

In this report, the part regarding the evaluation of the activity of the internal public audit in missions in the field of accounting activity (which also had as objective its own preventive financial control - CFPP) also found a series of shortcomings.

As deficiencies found in the activity of own preventive financial control by internal public auditors and reconfirmed by external public auditors are to be mentioned the following: 1) non-updating or non-compliance with the internal procedural framework for granting the preventive financial control visa (CFP), at the level of subordinated public entities (those relating to the establishment of the authorized persons, of the operations and documents subject to the CFP, of the circuit of documents, of the coordinating persons, of the separation of competencies and responsibilities, etc.); 2) documents that do not carry the CFP visa and documents targeted for the CFP but not included in the quarterly reports on the preventive financial control activity; 3) granting the CFP visa after the date on which the additional documents were concluded or approving the invoices for the CFP after the date on which the payment orders by which the respective invoices were paid were drawn up and registered.

Of course, these shortcomings and many others are reasons for dissatisfaction but also for intensification and correlation of efforts, both by the persons involved to grant the preventive financial control visa (own or delegated), and by internal and external public auditors to contribute to establishing and establishing an infallible financial control system, without cracks and omissions, as far as possible.

\section{Conclusions}

Financial control, as a component of internal / managerial and economic control, was conceptually examined by financial bodies from various professional bodies and public institutions abroad and in the country with financial-accounting and banking profile and led to the configuration a definition that focuses on the knowledge by the state of the way in which the material and financial means are administered by public institutions, the way of making and spending public money, ensuring financial balance, achieving economic and financial efficiency, developing the national economy, making progress social.

Financial control performs a number of functions such as: 1) evaluation function; 2) preventive function; 3) documentation function; 4) recovery function; 5) the pedagogical function and aims, among others, at a series of main objectives such as:1) elaboration of the revenue and expenditure budget and its execution; 2) increasing cash accumulations and ensuring the ability to pay; 3) increasing own financing resources; 4) permanent preservation of the patrimonial integrity; 5) discovery and recovery of damages, losses suffered; 6) liquidation of oversized expenses; 7) stopping the causes of waste; 8) compliance with financial and fiscal discipline.

Financial control in public institutions in our country is regulated under all aspects of two orders of the relatively recent Minister of Public Finance (OMFP no. 923/2014 and OMFP no. 103/2019), is classified in own and delegated preventive financial control and inserts a complex and demanding mechanism of procedures and procedures for granting the control visa for all documents of state institutions that require the proper use of public money. 
At the basis of the activity of the persons performing their own and delegated preventive financial control is a code of ethics that regulates the norms of conduct of these financial professionals,code that obliges these people to meet certain requirements, to respect certain principles, to avoid certain incompatibilities and failures that were reported by the internal and external public audit in previous years.

\section{References List}

[1] The paper appeared at the University Publishing House, Bucharest, 2017.

[2] The course was published in ASE Publishing House, Bucharest, 2005.

[3] Published at the Publishing House of the "Romania of Tomorrow" Foundation, Bucharest, 2007.

[4] Published in the Publishing House of "AI Cuza" University, Iași, 2015.

[5] Mihăescu Sorin, Financial-banking control. 4th edition revised and added, "AI Cuza" University Publishing House, Iași, 2015, p. 18.

[6] Munteanu Victor and collective, "Financial-accounting control at enterprisesand public institutions. Theory and practice-concepts, methodology, regulations, application.

[7] Boulescu Mircea, Financial-fiscal control, 2nd Edition, "Romania of Tomorrow" Foundation Publishing House, Bucharest, 2007, p. 16.

[8] Published in the Official Gazette of Romania, Part I, no. 28 of January 15, 2016.

[9] Published in the Official Gazette of Romania, Part I, no. 87 of February 4, 2019.

[10] Definition taken from Point 1.1 of Annex 1 entitled General methodological norms regarding the exercise of preventive financial control from OMFP no. 923/2014.

[11] Definition taken from Point 4.1. from chapter B. Own preventive financial control from Annex 1 entitled General methodological norms regarding the exercise of preventive financial control from OMFP no. 923/2014.

[12] Definition taken from Point 7.2. from chapter C. The delegated preventive financial control from Annex 1 entitled General methodological norms regarding the exercise of the preventive financial control from OMFP no. 923/2014.

[13] It refers to the approval of the Methodological Norms regarding the employment, liquidation, ordering and payment of the expenses of the public institutions, as well as the organization, evidence and reporting of the budgetary and legal commitments, published in the Official Gazette of Romania, Part I, no. 37 from 23.01.2003.

[14] This code canbefound in OMEF no. 1190 of 2004 on the approval of the Code of Ethics of the profession of delegated controller, published on www.mfinante.ro, accessed on 27.01.2021.

[15] Published as a paper in Bucharest, October 2018, p. 36. 